\title{
Writing History in a Propaganda Institute, Political Power and Network Dynamics in Communist Romania
}

\author{
Francesco Zavatti \\ Huddinge: Södertörns högskola 2016 \\ 387 sider. ISBN 9789187843457
}

\begin{abstract}
Anmeldt af: Rune Brandt Larsen [MA, doktorand, Lunds Universitet, rune.brandt_larsen@slav.lu.se]
\end{abstract}

Bogen er en doktorafhandling fra Södertörn Universitet, og i sin stil er den da også tydeligvis henvendt til et akademisk publikum. Den giver en meget tør og grundig gennemgang af begivenheder og omstændigheder knyttet til det rumænske institut for partihistorie under det kommunistiske styre. Men det er umagen værd at kæmpe sig igennem den, for den leverer nogle tankevækkende iagttagelser. Som det fremgår af titlen, beskæftiger bogen sig med spændingsfeltet mellem historie og propaganda. Det er et emne som der kan siges mange interessante ting om, eftersom historie ofte har vist sig at være en yderst værdifuld resurse for propagandaproducenter. Hvis historie bruges på den rigtige måde, kan den skaffe brugeren legitimitet og kulturel kapital, og den kan både knytte bånd og skabe grænser, hvis man ønsker det. Zavattis afhandling er et detailstudie af en specifik institution placeret i dette spændingsfelt.

Bogen indledes med en lang indføring $i$ al relevant baggrundsviden samt i det empiriske, metodiske og teoretiske grundlag. Med udgangspunkt i Foucault og Bourdieu kaster forfatteren sig ud i nogle betragtninger omkring magtstrukturer, organisationer og netværk. Det er dog ikke primært et teoretisk værk - det meste af opmærksomheden er samlet om konkrete historiske hændelser med udgangspunkt i det empiriske materiale der består af arkivkilder suppleret med interviews og sekundærlitteratur.

Hovedkapitlerne giver en kronologisk og meget udførlig gennemgang af hvad der foregik i og omkring instituttet for partihistorie lige fra grundlæggelsen i 1948 til nedlæggelsen i 1990. Forfatteren demonstrerer at instituttet ikke udelukkende fulgte ordrer fra kommunistpartiet, men rummede mange forskellige, ofte indbyrdes modstridende, dagsordener, grupperinger og personligheder. Der var ideologisk prægede netværk såsom »moskovitterne«, »de autoktone« og »veteranerne«. Der var netværk centreret om nogle konkrete magtfulde personer. Og så var der endelig spændingen mellem historikerne og propagandafolkene. Alle disse grupperinger var dynamiske og ustabile, og mange personer nåede at indgå i flere forskellige netværk i løbet af deres karriere. 
Samtidig var de naturligvis alle sammen i et afhængighedsforhold til magthaverne, og når de overhovedet havde et vist manøvrerum, skyldtes det blandt andet at magthaverne også havde brug for historikerne. I bestræbelserne på at skabe en national kommunisme og reducere afhængigheden af Sovjetunionen forsøgte man at alliere sig med den akademiske verden og sætte historikerne til at styrke partiets legitimitet. Og historikerne accepterede i vidt omfang disse arbejdsvilkår, fordi de simpelthen vægtede deres egne interesser højere end videnskabens eller ideologiens. I den konstante kamp om resurser, positioner og privilegier forsøgte folk at indgå i de alliancer der helt aktuelt fremmede deres egen sag bedst muligt. De indgik i en relation hvor der blev udvekslet resurser i bytte for kulturel kapital. Som læser farer man nemt vild $\mathrm{i}$ alle detaljerne, men heldigvis opsummeres de vigtigste pointer i slutningen. Der er tale om et værk der føjer nogle interessante detaljer til den akademiske viden.

Bogens berettigelse ligger for det første $i$ at den nuancerer billedet af den konkrete institution og det system den indgik i. Kommunistiske regimer fremstilles ofte som umenneskelige, ensrettede systemer, men denne bog demonstrerer at selv sådan et system er bygget op af mennesker og at den tilsyneladende ensretning kan dække over et mylder af modstridende tendenser. Bogens værdi består for det andet i at den føjer vigtige nuancer til vores viden om historieskrivning og historiebrug. At statssponsoreret historie $\mathrm{i}$ et autoritært regime er underlagt politiske hensyn, er nok ikke så overraskende. Men denne afhandling blotlægger en masse mellemregninger som man ellers sjældent ser. Den demonstrerer hvordan magthavere kan manipulere med historiesynet, men også hvordan de ind imellem mister grebet og bliver fanget af deres egne tidligere manipulationer. Og den viser at der godt kan være flere relevante aktører involveret, og at personlige netværk også kan have noget at sige.

Endelig er bogens konklusioner tankevækkende i et bredere perspektiv. Forfatteren slutter af med at drage paralleller til nutiden og hævde at også demokratiske stater har et fast greb om historieskrivningen i kraft af deres økonomiske magt, og at den konstante kamp om resurser betyder at den historiske sandhed og professionalisme altid er til forhandling. 